Invertebrate Biology 132(2): 163-172.

(C) 2013, The American Microscopical Society, Inc.

DOI: $10.1111 /$ ivb. 12022

\title{
Morphology of the fifth sternal glands of Neotropical social wasps (Hymenoptera, Vespidae, Polistinae)
}

\author{
Ernesto Samacá, ${ }^{1}$ Johan Billen, ${ }^{2}$ and Carlos E. Sarmiento ${ }^{1, a}$ \\ ${ }^{1}$ Laboratorio de Sistemática y Biología Comparada de Insectos, Instituto de Ciencias Naturales, \\ Universidad Nacional de Colombia, Bogotá, Colombia \\ ${ }^{2}$ Zoological Institute, University of Leuven, Leuven B-3000, Belgium
}

\begin{abstract}
Glands play a central role in the social behavior of insects, and comparative analysis of their structure may provide insights about their evolution and their role in insect social biology. Here, we describe the glands of the fifth metasomal sternite of ten polistine wasps with different social behaviors. The glands of foragers of these species were studied using semithin sections of Araldite-embedded tissue, and scanning electron microscopy. The structure of the glands observed was mostly similar to what has previously been reported for independent-founder and swarm-founder species, respectively. Scale-shaped modifications in the fifth sternite are reported for the first time for members of the genera Synoeca and Epipona. Two previously unreported glands in the fifth sternite are also described. A more restrictive definition of the name Richards' gland is proposed, applying to the class 3 cells associated with scale modifications of the fifth sternite, based on structural differences between the glands observed, homology requirements, and functional evidence. Previous phylogenetic reconstructions of this character suggest that it appeared early in the Vespidae and disappeared four times, with a single reappearance in the genus Vespula. The restricted definition of Richards' gland suggests that this structure is an exclusive trait of the Epiponini, with two reversals.
\end{abstract}

Additional key words: Epiponini, Richards' gland, conjunction homology test

Glandular organs that vary in structure and complexity have been reported in the fifth metasomal sternite of the social wasps (Hymenoptera, Vespidae). Heselhaus (1922) was the first to describe a cluster of cells with their respective ducts, which was later named Richards' gland (Jeanne \& Post 1982), as it was Richards (1971) who called attention to the distribution of this gland within the Vespidae. The cells discharge their products through their ducts into the invaginated sternal intersegmental membrane located between sternites 4 and 5, which acts as a reservoir. The gland cells are "class 3 " cells according to the classification by Noirot \& Quennedey (1974). These authors define class 3 cells by the presence of a duct that connects the cell directly to the cuticle or to a reservoir where the product is released.

In addition to these cells, there are scale-shaped modifications of the exoskeleton where the ducts

\footnotetext{
${ }^{a}$ Author for correspondence.

E-mail: cesarmientom@unal.edu.co
}

open to the exterior of the body; these modifications were used by Richards (1971) to record the distribution of the gland within neotropical polistines. In 1982, Jeanne \& Post defined Richards' gland as an organ composed of class 3 cells associated by a series of ducts with a modified area of the cuticle located at the base of the fifth sternite.

Naumann (1975) proposed that this gland secretes substances that are used to mark trails during the foundation of a new colony, as scouts mark the trails between old and new nests with chemical signals by rubbing their ventral metasoma on the vegetation. This idea was later confirmed by Jeanne (1981), who established a relationship between the presence of the gland and swarm-founding of colonies. Since then, several publications have recorded the taxonomic distribution and structural variation of these glands within Polistinae (Landolt \& Akre 1979; Jeanne \& Post 1982; Jeanne et al. 1983; Billen \& Noll 2011).

There have also been reports of a gland composed of a conspicuous layer of secreting cells attached to 
the internal part of the fifth sternite (Turillazzi 1979; Post \& Jeanne 1980); these are class 1 cells according to the classification of Noirot \& Quennedey (1974). No associated skeletal modifications have been reported in these cases (Turillazzi 1979; Post \& Jeanne 1980). This type of gland has been reported only in members of the genera Polistes and Mischocyttarus. In these genera, the colony starts with a single foundress, without the support of a swarm (Post \& Jeanne 1980; Jeanne et al. 1983).

Despite the experimental evidence provided by Jeanne (1981) and Naumann (1975) regarding the function of Richards' gland in Polybia sericea (OLIVIER 1791) and Angiopolybia pallens (LEPELETIER 1836), respectively, the taxonomic distribution of this gland does not entirely match the distribution of swarmfounder species. There are no records of class 3 cells or of scaly modifications at the base of the fifth sternite in members of some swarm-founder genera, such as Angiopolybia, Parachartergus, Chartergellus, Leipomeles, and Agelaia. Previous records provided by Naumann (1975) for Agelaia were later found to be incorrect (Jeanne et al. 1983). On the other hand, Litte (1981) reports trail-marking behaviors in the independent-founder species Mischocyttarus labiatus (FABRICIUS 1804). In addition, in the independent-founder genus Vespa, Richards' gland has been reported to be present (Smith et al. 2002), as well as rubbing behavior (Martin 1992) and the use of terrestrial trails (Steinmetz et al. 2002).

Post \& Jeanne (1980) and Jeanne et al. (1983) reported class 1 and class 3 cells in eight species of the independent-founder genera Mischocyttarus and Polistes, although no skeletal modifications have been reported. Here, we describe the fifth sternite glands in ten species that have not been studied previously in this regard. In addition, based on morphological differences and phylogenetic considerations, we propose a new, more restrictive definition of Richards' gland.

\section{Methods}

Foragers of the ten species used for the analysis were captured in various places in Colombia. Polistes aterrimus DE SAUSSURE 1853 and Mischocyttarus angulatus RICHARDS 1945 are species representative of the independent-founder strategy, where colonies are initiated by one or several inseminated queens independently of any workers. The other eight species are representative of the swarm-founder strategy, where the colonies are initiated by swarms of queens and workers (Jeanne 1991): Agelaia areata (SAY 1837), Brachygastra lecheguana (LATREILle 1824), Epipona niger (BRETHES 1926), Leipomeles spilogastra (CAMERON 1912), Metapolybia aztecoides Richards 1978 , Polybia ignobilis (Haliday 1836), Protopolybia amarella BEQUAERT 1944, and Synoeca septentrionalis RICHARDS 1978. Species were identified by the last author using appropriate literature.

Between one and three specimens per species were killed immediately prior to dissection, to preserve cell integrity. The last three metasomal segments of every specimen were submerged in $2 \%$ glutaraldehyde in $50 \mathrm{mmol} \mathrm{L}^{-1}$ sodium cacodylate buffer for $12 \mathrm{~h}$ at $4^{\circ} \mathrm{C}$. Samples were transferred to fresh buffer, then dehydrated in a graded acetone series before embedding in Araldite. Semithin serial sections (thickness $2 \mu \mathrm{m}$ ) were obtained with a Reichert E ultramicrotome, and were stained with methylene blue and thionin. All sections were made longitudinally. Sections were imaged using a Carl Zeiss Jenawal light microscope and photographed with a digital camera. By examining serial sections, the number of cells per gland was recorded. All histological sections shown in this study are oriented with the anterior end to the left. Specimens prepared for scanning electron microscopy (by air-drying and sputter-coating with gold) were viewed with an FEI Quanta 200 microscope at low voltage (25-30 kV).

\section{Results}

\section{Independent-founder species}

Members of Mischocyttarus angulatus had three types of glandular cells at the fifth sternite. A clear layer of class 1 cells extending $350 \mu \mathrm{m}$ distally from the base of the antecostal ridge was attached to the sternite. Transversely, the layer extended $1.8 \mathrm{~mm}$ (Fig. 1A,B). These glandular epithelial cells (ge) had a rectangular shape, with a maximal thickness of $\sim 22 \mu \mathrm{m}$ (Fig. 1B). We also observed two sets of class 3 cells, with ducts that reached the sternite wall through the layer of class 1 cells mentioned above (Fig. 1B). The first set of class 3 cells (gc1) was composed of spherical cells with a mean diameter of $27 \pm 1.5 \mathrm{SD} \mu \mathrm{m}(\mathrm{n}=10)$. These were clustered on the antecostal ridge. Around 220 of these cells were identified, extending $\sim 60 \mu \mathrm{m}$ distally and $2.0 \mathrm{~mm}$ transversely. Ducts of this cluster of class 3 cells opened through the epithelium and extended posteriorly to the antecostal ridge. The second set of class 3 cells ( $\mathrm{gc} 2$ ) was composed of spherical cells $24.5 \pm 1.3 \mu \mathrm{m}(\mathrm{n}=10)$ in diameter (Fig. 1B). These cells were less vacuolated than those of $\mathrm{gcl}$, and were connected to the sternite by long ducts that passed through the epithelium. Gc2 cells were 

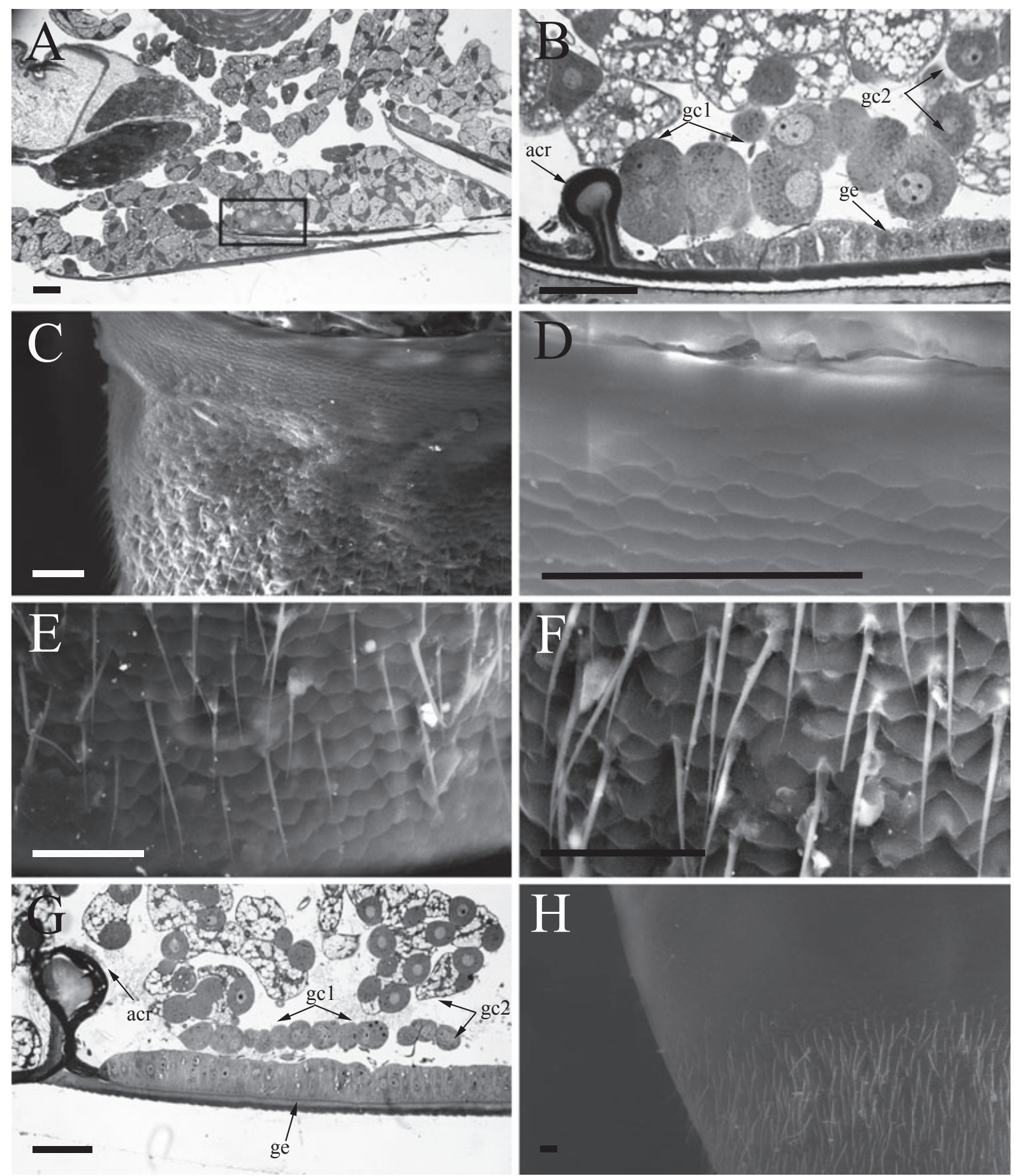

Fig. 1. The metasoma of the independent-founder wasps Mischocyttarus angulatus and Polistes aterrimus. A. Overview of the distal metasomal region of $M$. angulatus, indicating the location of the fourth and fifth sternites. The frame indicates the close-up region in B. B. Semithin section of the fifth sternite of $M$. angulatus, where the three types of glandular cells are observed. Note the absence of a reservoir. C, D. Scanning electron micrographs of the fifth sternite of $M$. angulatus, indicating the absence of skeletal modifications at its base. E, F. Scanning electron microscopy of the fifth sternite of $M$. angulatus, indicating the rugous area that extends posteriorly and is covered by irregular scales and setae. G. Semithin section of the fifth sternite of $P$. aterrimus, where the three types of glandular cells are observed. H. Scanning electron micrograph of the fifth sternite of $P$. aterrimus, indicating the absence of skeletal modifications at its base and the rugous area that extends posteriorly. Scale bars $=50 \mu \mathrm{m}$. acr, antecostal ridge; gc1, first set of class 3 glandular cells; gc2, second set of class 3 glandular cells; ge, glandular epithelium. 
scattered beneath the epithelial cells and surrounded by what appeared to be a cloud of adipose cells (Fig. 1B). No reservoir was observed (Fig. 1B), nor any modifications of the anterior area of the sternite (Fig. 1C,D). At a distance of $\sim 200 \mu \mathrm{m}$ anterior from the border of the antecostal ridge, an extensive modification of the skeleton was observed (Fig. 1E,F).
This modification covered $\sim 80 \%$ of the sternite, but did not reach its anterior end. The irregular surface of the sternite was formed by scales, setae, and pores that gave it a rugose texture (Fig. 1F).

Members of Polistes aterimus were similar in form to those of $M$. angulatus. An epithelium extended $400 \mu \mathrm{m}$ along the anterior-posterior axis
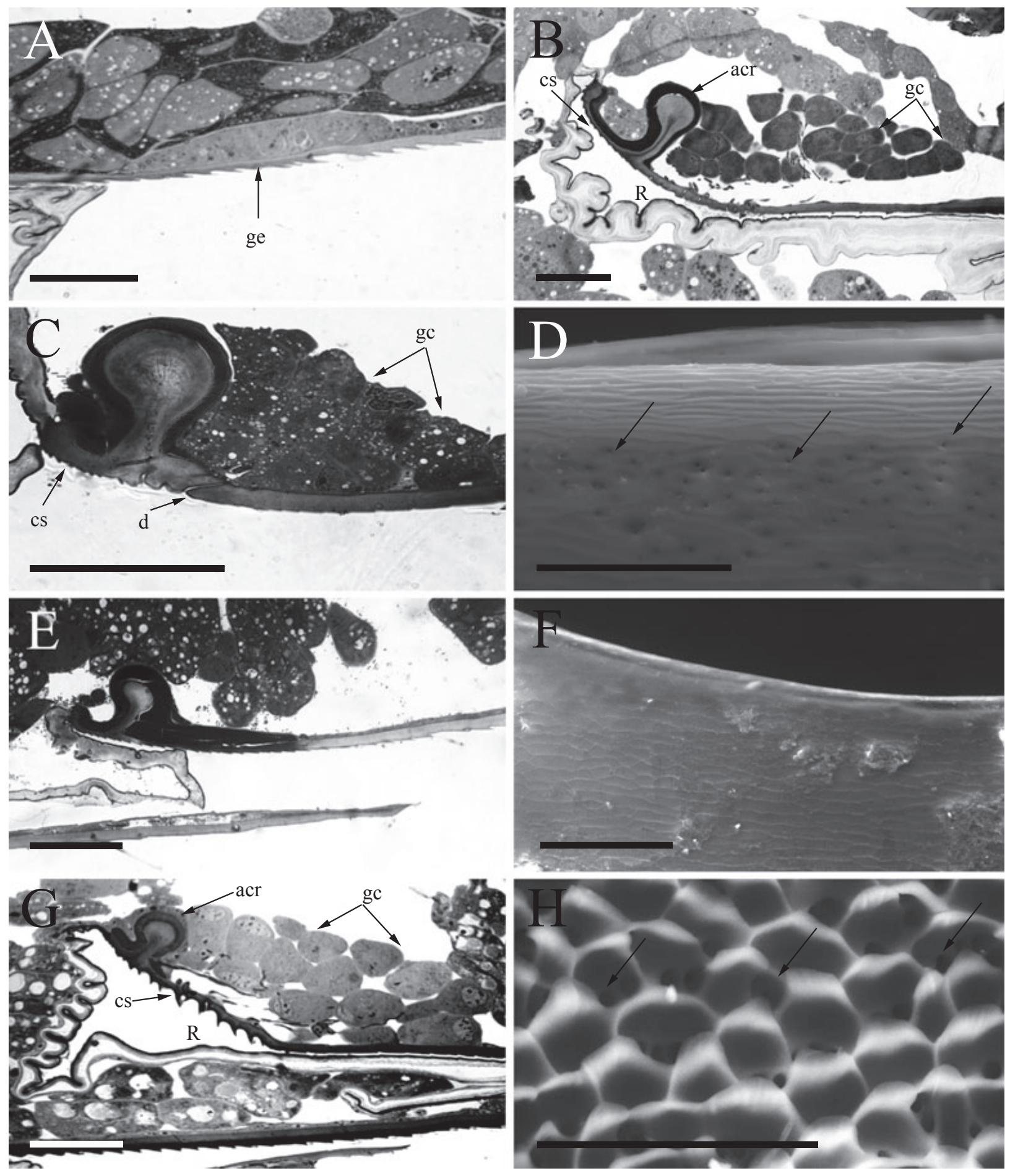
from the antecostal ridge, and $2 \mathrm{~mm}$ transversely across the sternite. This layer was composed of rectangular class 1 cells with a thickness of $\sim 21.7 \mu \mathrm{m}$ (Fig. 1G). Members of this species also had two different clusters of class 3 cells. The first was located along the antecostal ridge and was composed of spherical cells with an average diameter of $24.4 \pm 1.9 \mu \mathrm{m} \quad(\mathrm{n}=10)$. This gland comprised $\sim 160$ cells that extended $1.2 \mathrm{~mm}$ transversely and $75.3 \mu \mathrm{m}$ longitudinally (Fig. 1G). Class 3 cells in the second set had an average diameter of $21.9 \pm 1.3 \mu \mathrm{m}(\mathrm{n}=10)$. These cells were smaller than those of first cluster, and were scattered beneath the epithelium (Fig. 1G). Ducts of both clusters of class 3 cells opened through the epithelium and extended posterior to the antecostal ridge. There were no cuticular modifications in the basal region of the sternite, while the distal region had a rugose surface very similar to that described in $M$. angulatus (Fig. 1H).

\section{Swarm-founding species}

Agelaia areata had a single secretory cell aggregation in the fifth sternite. Contrary to the negative records of glands on the fifth sternite of this species (Jeanne et al. 1983), we observed a glandular epithelium of class 1 cells (Fig. 2A). This layer originated $70 \mu \mathrm{m}$ posterior to the antecostal ridge and extended $130 \mu \mathrm{m}$ distally and $2.4 \mathrm{~mm}$ transversely, covering most of the sternite. Epithelial cells had an irregular shape and a maximum height of $19.1 \mu \mathrm{m}$ (Fig. 2A). No class 3 cells were observed in the fifth sternite of this species.

Brachygastra lecheguana had a gland composed of class 3 secretory cells. This cluster of cells was found posterior to the antecostal ridge, and extended $710 \mu \mathrm{m}$ transversely and $230 \mu \mathrm{m}$ longitudinally. The spherical cells had an average diameter of $23.8 \pm 0.8 \mu \mathrm{m}(\mathrm{n}=10) ; 420$ of these cells were counted in the gland (Fig. 2B). No epithelial glands were observed in this species.
Epipona niger had a gland composed of class 3 cells. This group of cells extended $260 \mu \mathrm{m}$ distally and $0.95 \mathrm{~mm}$ transversely. Approximately 253 secretory cells were identified, each with an average diameter of $24.7 \pm 1.2 \mu \mathrm{m} \quad(\mathrm{n}=10)$ (Fig. 2C). These glands discharge their contents through ducts into a reservoir; however, cuticular modifications were also observed as very small scales that have gone unnoticed in the descriptions of previous studies (Jeanne et al. 1983) (Fig. 2C,D). No epithelial glands were observed in this species.

Leipomeles spilogastra did not show any trace of glands (Fig. 2E) or cuticular modifications in the fifth sternite (Fig. 2F). These records agree with the literature (Naumann 1975; Jeanne et al. 1983).

Metapolybia aztecoides had a cluster of class 3 cells located posterior to the antecostal ridge. This gland extended $180 \mu \mathrm{m}$ longitudinally and $670 \mu \mathrm{m}$ transversely. Approximately 361 spherical cells were counted, with an average diameter of $29.9 \pm 1.8 \mu \mathrm{m}$ $(n=10)$ (Fig. 2G). A reservoir formed by the intersegmental membrane between the fifth and fourth sternite was observed (Fig. 2G). The anterior outer surface of the sternite was modified by scaleshaped cuticular projections (Fig. $2 \mathrm{H}$ ). No epithelial glands were observed in this species.

Polybia ignobilis had a large cluster of class 3 cells at the anterior margin of the fifth metasomal sternite (Fig. 3A,B). These cells were located above the antecostal ridge and extended longitudinally $\sim 150 \mu \mathrm{m}$. The maximum transverse extension of the cluster was close to $1.0 \mathrm{~mm}$. The cells were pear shaped, with an average diameter of $31.5 \pm 2.1 \mu \mathrm{m}$ $(n=10)$. Around 470 cells were counted. All ducts extended toward the basal area of the sternite, close to the antecostal ridge (Fig. 3B). A large reservoir was formed by the invagination of the intersegmental membrane (Fig. 3B). The sternite surface was smooth in its posterior region (Fig. 3C), but the anterior border of the sternite, where the ducts were located, was covered by scales (Fig. 3B,D), and

Fig. 2. The metasoma of the swarm-founders Agelaia areata, Brachygastra lecheguana, Epipona niger, and Metapolybia aztecoides. A. Semithin longitudinal section along the fifth sternite of the metasoma of A. areata. Notice the absence of class 3 gland cells. B. Semithin longitudinal section along the fifth sternite of B. lecheguana. C. Semithin longitudinal section along the fifth sternite of E. niguer. Notice the pores and the small scales proximal to the antecostal ridge. D. Scanning electron microscopy of the fifth sternite of E. niguer; pores and the small scale modifications are observed. $\mathbf{E}$. Semithin longitudinal section along the fifth sternite of L. spilogastra, indicating the absence of glandular cells. F. Scanning electron micrograph of the fifth sternite of L. spilogastra. Notice the absence of cuticular modifications. G. Semithin longitudinal section along the midline of the fifth sternite of M. aztecoides. H. Scanning electron microscopy of the fifth sternite of $M$. aztecoides, indicating the cuticular scaly area at the anterior part of the sternite. The arrow points to the pores. acr, antecostal ridge; cs, cuticular scales; d, ducts; gc, class 3 gland cells; ge, glandular epithelium composed of class 1 cells; R, reservoir formed by the invagination of the intersegmental membrane located between the fourth and fifth sternites. Scale bars $=50 \mu \mathrm{m}$. 

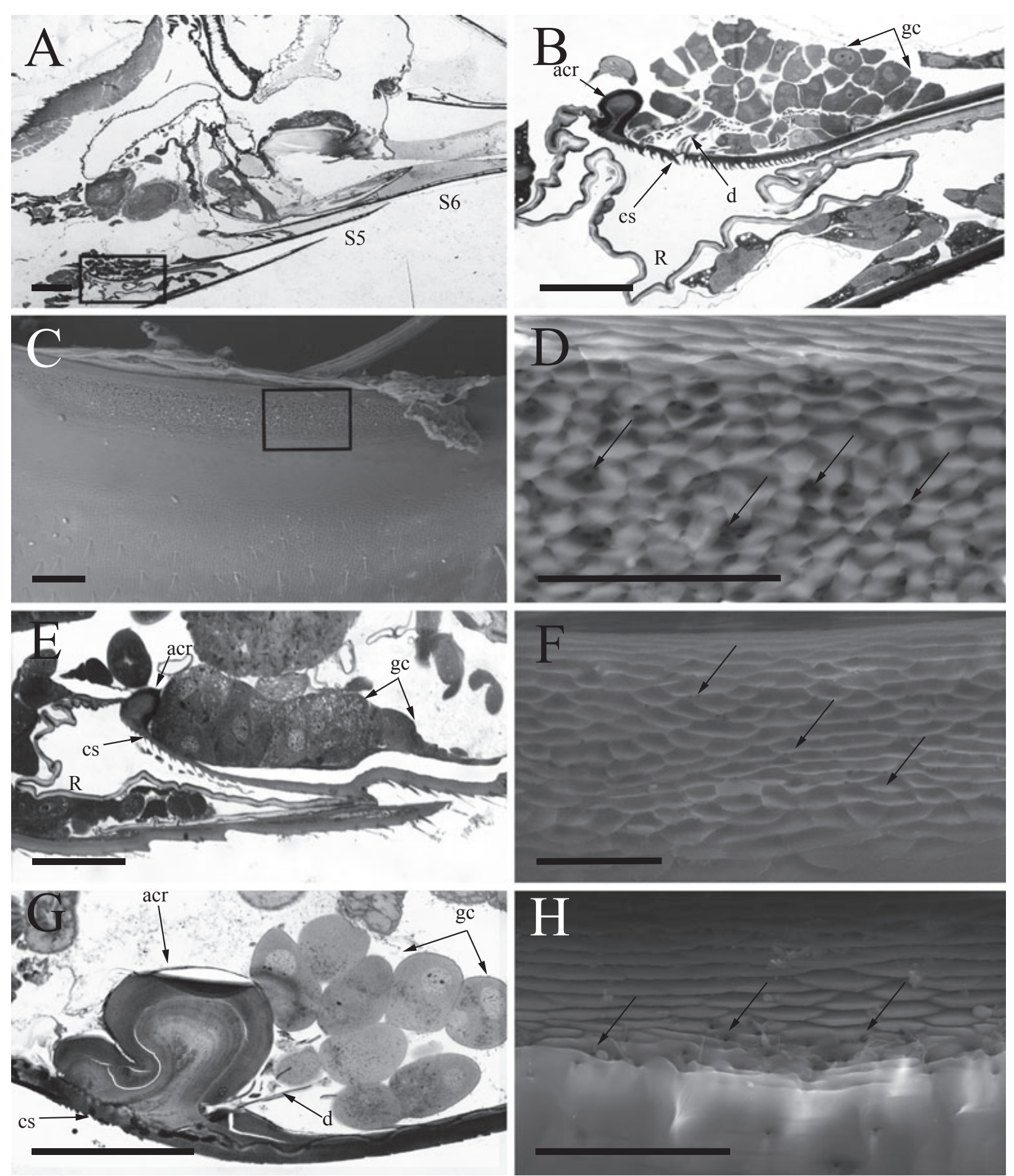

pores were observed in this area (Fig. 3D). No epithelial glands were observed in this species.

Protopolybia amarella had a set of class 3 cells that extended $190 \mu \mathrm{m}$ distally and $560 \mu \mathrm{m}$ transversely. Around 365 cells were identified, with an average diameter of $24.1 \pm 2.1 \mu \mathrm{m} \quad(\mathrm{n}=10)$ (Fig. 3E). Both reservoir and cuticular modifications in the form of scale projections were observed (Fig. 3F). No epithelial glands were observed in this species.

In Synoeca septentrionalis, the fifth sternite had a gland of class 3 spherical cells that extended $\sim 120 \mu \mathrm{m}$ longitudinally from the antecostal ridge and $\sim 2 \mathrm{~mm}$ transversely. Approximately 400 spherical cells, with an average diameter of $28 \pm 1.5 \mu \mathrm{m}$ 
Fig. 3. The metasoma of the swarm-founder species Polybia ignobilis, Protopolybia amarella, and Synoeca septentrionalis. A. Overview of the distal region of the metasoma of $P$. ignobilis showing fifth (S5) and sixth (S6) sternites; the frame indicates the close-up region in B. Scale bar $=100 \mu \mathrm{m}$. B. Detail of the anterior region of the fifth sternite in $P$. ignobilis. Scale bar=50 $\mu \mathrm{m}$. C, D. Scanning electron micrographs of the fifth sternite of P. ignobilis, indicating the cuticular scaly area at the anterior part of the sternite; the frame in C indicates the close-up region in D. The arrow in D points indicates the pores. Scale bars $=50 \mu \mathrm{m}$. E. Semithin longitudinal section along the fifth sternite of $P$. amarella. Scale bar $=50 \mu \mathrm{m}$. F. Scanning electron micrograph of the fifth sternite of $P$. amarella. Scale bar=50 $\mu \mathrm{m}$. G. Semithin longitudinal section along the midline of the metasoma of $S$. septentrionalis. Scale bar=50 $\mu$ m. H. Scanning electron micrograph of the anterior border of the fifth sternite in S. septentrionalis showing the location of the scales and openings of cellular ducts next to the antecostal ridge (arrow). Scale bar=50 $\mu \mathrm{m}$. acr, antecostal ridge; cs, cuticular scales; d, ducts; gc, class 3 gland cells; R, reservoir formed by the invagination of the intersegmental membrane located between the fourth and fifth sternites.

$(\mathrm{n}=10)$, were recorded. The ducts extended toward the posterior area of the antecostal ridge (Fig. 3G). Unlike previous descriptions of other Synoeca species in which only pores were reported (Jeanne et al. 1983), we observed an area with very small scales located anterior to the antecostal ridge (Fig. 3G,H). No epithelial glands were observed in this species.

\section{Discussion}

Except for Agelaia areata, which does not have class 3 glands, and Leipomeles spilogastra, which does not have any gland on its fifth sternite, we observed five major differences in the structure of the fifth sternite glands between the swarm-founder species and the independent-founder species (Fig. 4):

(1) There were no scale-shaped skeletal modifications at the base of the sternite in the independent-founders, while these were present in the swarm-founder species.

(2) In the independent-founders, the area posterior to the antecostal ridge was smooth proximally, but rugose distally, with widespread pores that cover most of the sternite; in the swarm-founder species there was no rugose area, and the surface was entirely smooth posterior to the scale-shaped modification.

(3) Class 1 cells were numerous in independentfounders and found adjacent to the external rugous surface of the sternite; except for $A$. areata, the swarm-founder species did not have class 1 cells in the fifth sternite.

(4) The ducts of class 3 cells opened only on the posterior side of the antecostal ridge in the independent-founder species, while in swarm-founder species these ducts were directed toward the base of the sternite and opened both anteriorly and posteriorly to the antecostal ridge.

(5) Independent-founder species had a second set of class 3 glandular cells that was embedded within fat cells, with their ducts traversing the epithelial gland (gc2 in Table 1 and Fig. 4).
Most literature reports on the Polistinae are consistent with the above-described differences between the swarm-founder and independent-founder species studied (Downing 1991; Jeanne 1991) (Table 1). The descriptions and published figures of several species of Vespa, Mischocyttarus, and Polistes agree with what we have described for $M$. angulatus and $P$. aterrimus as independent-founder species (Heselhaus

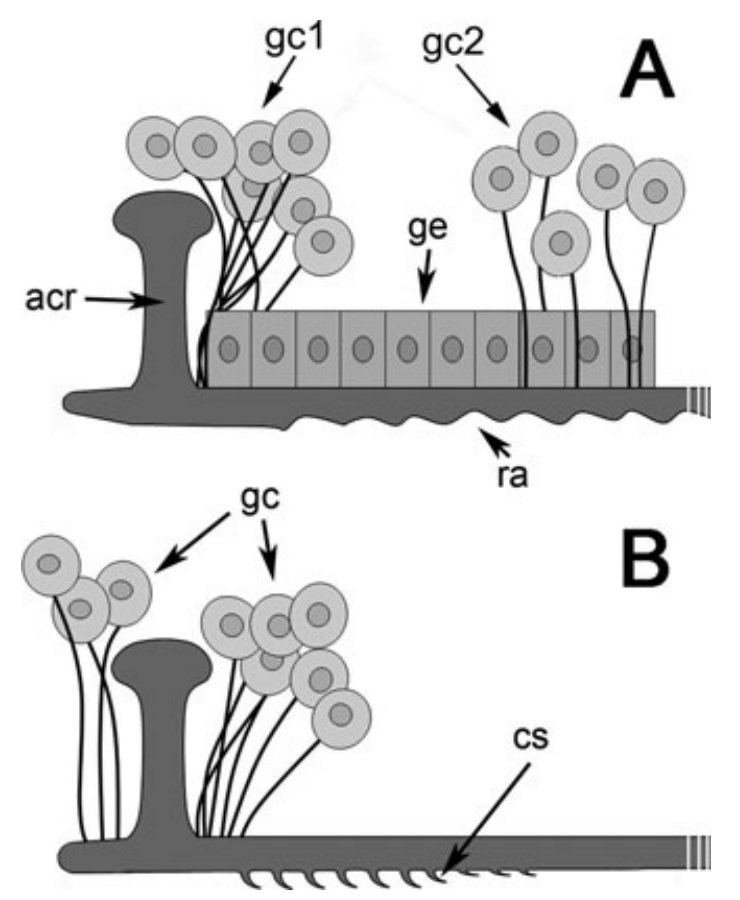

Fig. 4. Schematic profile of the differences observed between independent-founder species (A) and swarmfounder species (B). Independent-founder species exhibit three glandular cell groups, a class 1 epithelial layer (ge) that extends distally to the antecostal ridge (acr), and two clusters of class 3 cells, the first one ( $\mathrm{gcl}$ ) close to the antecostal ridge and the second one ( $g c 2)$ distal to this. Swarm-founder species only exhibit a class 3 gland close to the antecostal ridge. The tergite modifications are rugose (ra) in swarm-founder species, while these are scale shaped (cs) in swarm-founder species. 
Table 1. Summary of gland cell reports and associated cuticular modifications on the fifth sternite in female Vespidae. gcl=class 3 cells, corresponding to Richards' gland according to its original definition; gc $2=$ second set of class 3 cells observed in this study; ge=class 1 cells. References are A, Landolt \& Akre 1979; B, Post \& Jeanne 1980; C, Jeanne et al. 1983; D, Jeanne \& Post 1982; E, this study. An asterisk (*) indicates that published images are available, but they are not clear enough to determine whether the second set of class 3 cells is present in the species.

\begin{tabular}{|c|c|c|c|c|c|}
\hline Species & $\mathrm{gc1}$ & gc2 & ge & Cuticular modification & Reference \\
\hline \multicolumn{6}{|l|}{ Independent-founder species } \\
\hline Mischocyttarus angulatus RICHARDS 1945 & + & + & + & Pores, rugous area & E \\
\hline Mischocyttarus flavitarsis (De SAussure 1854) & + & $?$ & + & Pores & A \\
\hline Polistes aterrimus De SAUSSURe 1853 & + & + & + & Pores, rugous area & $\mathrm{E}$ \\
\hline Polistes canadensis (LinNaEus 1758) & + & $?^{*}$ & + & Pores & B \\
\hline Polistes infuscatus (FABRICIUS 1793) & + & $?^{*}$ & + & Pores & B \\
\hline Vespa crabro LinNaEus 1758 & + & $?$ & - & Pores & A \\
\hline Vespula squamosa (DRURY 1770) & + & $?$ & - & Pores & A \\
\hline \multicolumn{6}{|l|}{ Swarm-founder species } \\
\hline Agelaia areata (SAY 1837) & - & - & + & Absent & E \\
\hline Agelaia testacea (FABRICIUS 1804) & - & ? & - & Absent & $\mathrm{C}$ \\
\hline Angiopolybia pallens (LEPELETIER 1836) & - & ? & - & Absent & $\mathrm{C}$ \\
\hline Apoica pallida (OLIVIER 1792) & + & ? & - & Brush of setae & $\mathrm{C}$ \\
\hline Brachygastra augusti (De SAUSSURe 1854) & + & $?$ & - & Cuticular scales & $\mathrm{C}$ \\
\hline Brachygastra lecheguana (LATREILLE 1824) & + & - & - & Cuticular scales & $\mathrm{E}$ \\
\hline Chartergellus communis RICHARDS 1978 & ? & ? & $?$ & Absent & $\mathrm{C}$ \\
\hline Epipona niger (BRETHES 1926) & + & - & - & Cuticular scales & E \\
\hline Epipona tatua (CUvIER 1797) & + & ? & - & Pores & $\mathrm{C}$ \\
\hline Leipomeles dorsata (FABRICIUS 1804) & - & $?$ & - & Absent & $\mathrm{C}$ \\
\hline Leipomeles spilogastra (CAMERON 1912) & - & - & - & Absent & E \\
\hline Metapolybia aztecoides RICHARDS 1978 & + & - & - & Cuticular scales & E \\
\hline Metapolybia docilis RICHARDS 1978 & + & $?$ & - & Cuticular scales & $\mathrm{C}$ \\
\hline Nectarinella championi (DOvER 1925) & $?$ & $?$ & $?$ & Absent & $\mathrm{C}$ \\
\hline Polybia ignobilis (HaLIDAY 1836) & + & - & - & Cuticular scales & E \\
\hline Polybia occidentalis (OlIVIER 1791) & + & - & - & Cuticular scales & $\mathrm{D}$ \\
\hline Protopolybia amarella BEQUAERT 1944 & + & - & - & Cuticular scales & $\mathrm{E}$ \\
\hline Protopolybia scutellaris BEQUAERT 1944 & $?$ & ? & ? & Cuticular scales & $\mathrm{C}$ \\
\hline Synoeca septentrionalis RICHARDS 1978 & + & - & - & Cuticular scales & $\mathrm{E}$ \\
\hline Synoeca surinama (LinNAEus 1767) & + & $?$ & - & Cuticular scales & $\mathrm{C}$ \\
\hline
\end{tabular}

1922; Post \& Jeanne 1980; Jeanne et al. 1983). However, two exceptions occurring in the swarmfounder species should be pointed out: first, the members of clades Angiopolybia-Agelaia and Parachartergus-Leipomeles-Chartergellus-Nectarinella do not have class 3 glands in the fifth sternite; second, members of the genus Apoica have a brush of cuticular setae instead of scale modifications (Jeanne et al. 1983). The genus Protonectarina should be studied in more detail. Smith et al. (2002) indicated that they analyzed members of this genus and, according to their phylogenetic tree, glands on the fifth sternite are present (see their figure 2); however, no data on this genus are listed in their table 1, where they record gland presence and associated behavioral traits. Despite the location of Protopolybia within a clade (Synoeca-Epipona) where all the studied species have glands on the fifth sternite, our study shows the importance of detailed comparisons to clear up the nature of the organs present in this sternite.

It is important to point out that in the literature pores, but not scales, have been reported in the species Synoeca surinama (Linnaeus 1767) and Epipona tatua (Cuvier 1797) (Jeanne et al. 1983), and thus, the absence of scales has been implied for both genera; however, our sections and SEM images of $S$. septentrionalis and E. niguer revealed pores and a small band of reduced scales at the base of the antecostal ridge. We assume that the negative reports may have been a consequence of the small size of this structure in members of these genera.

Jeanne et al. (1983) and Downing (1991) reported that Richards' gland in some species of Mischocyttarus, 
Polistes, and Ropalidia is composed of a narrow to a broad band of class 3 and class 1 cells. On the other hand, Jeanne et al. (1983), Downing (1991), and Smith et al. (2002) define Richards' gland as having several cuticular modifications instead of a restricted band of scale-like projections. We argue that the use of the name Richards' gland for any aggregation of secretory cells located in the fifth metasomal sternite poses several challenges for a comparative study of this trait.

First, the fifth metasomal sternite could be a large enough structure to hold several organs with different functions and evolutionary histories. We have pointed out several glands that differed in at least five morphological traits between the independent and in the swarm-founder species of social wasps. These observations lead us to suggest that classifying a gland only by the presence of any secreting cell in the sternite is inappropriate.

Second, any reconstruction of the phylogenetic history of Richards' gland requires a precise definition of the character. The homology of shared characters between taxa should not rely only on topographic correspondence; compositional similarity must also be considered (Patterson 1982; Hawkins et al. 1997; Nixon \& Carpenter 2012). In addition, if several states of the character are present in a single individual, this observation challenges the proposition that these states belong to the same character (Patterson 1982). Class 1 and class 3 cells were observed in the same individuals of independent-founder species. In addition, we found two types of class 3 cells in $M$. angulatus and $P$. aterrimus.

Third, the function of Richards' gland is not clear. The proposed relationship between this gland and trail-following behavior is complicated by the distribution of both traits in Polistinae, as described in the introduction; indeed, Smith et al. (2002) have come to the conclusion that this gland is not related to trail-following behavior. In addition, Dani et al. (1995, 1996) have demonstrated that ant-repellent compounds are produced in the glands located in the fifth as well as the sixth sternites in Polistes species, and thus, that the presence of class 1 cells in the fifth sternite of single-founder species is evidence that these are Richards' glands could be questioned. This lack of a relationship between the gland and its hypothesized function has been reported in other cases, such as the multiple glands that can be involved in trail-pheromone production among ants (Billen \& Morgan 1998).

Based on the described structural differences in the fifth sternite gland among species, the problems associated with the comparative morphology of these glands, and the lack of data to establish the function of Richards' gland, we suggest restricting the name "Richards' gland" to the cluster of class 3 cells associated with scale-shaped skeletal modifications of the surface of the fifth sternite by a series of ducts oriented to the base of the antecostal ridge of that sternite. This definition excludes the second cluster of class 3 cells and the class 1 cells observed in members of several species. Most of the described characteristics of Richards' gland were originally identified by Heselhaus (1922) and Richards (1971), and these were the criteria used by Jeanne \& Post (1982) to name this structure after the latter author. Our proposed definition of the Richards' gland is consistent with the first mentions of this organ in Polistinae, although the details about the duct orientation are new requirements. Other types of gland cells such as the two we describe here may correspond to overlooked glands also present in the fifth sternite.

In their study of the history of swarm communication in social wasps, Smith et al. (2002) argued that a group of any type of glandular cell in the fifth sternite should be considered as a Richards' gland. This relaxed concept of the gland led them to the conclusion that this trait had evolved early in the history of the Vespidae, and disappeared four times, with a single reappearance in Vespula. The restricted application of the name that we propose here turns this structure into an exclusive trait of the Epiponini with two reversals, one in the Angiopolybia-Agelaia clade and another in the Parachartergus-Leipomeles-Chartergellus-Nectarinella clade.

Although this proposal does not solve the uncertainty about the function of the gland, it allows for a different research focus and makes the reconstruction of the gland's history more consistent with current thought in comparative biology and systematics. The glands observed in Mischocyttarus, Polistes, Vespa, and Vespula require more detailed morphological characterization, and may eventually be interpreted as glands that are not homologous to Richards' gland in other taxa.

Acknowledgments. We are very grateful to An Vandoren for her skillful help in section preparation. We also thank Adriana Antolines of the Laboratorio de Microscopía Electrónica of the Universidad Nacional de Colombia. We thank the referees for their helpful comments. This project was partially funded by the Bogotá Branch of the Research Division of the Universidad Nacional de Colombia (to EJS and CES). The authors declare no conflict of interest. 


\section{References}

Billen J \& Morgan ED 1998. Pheromone communication in social insects-sources and secretions. In: Pheromone Communication in Social Insects: Ants, Wasps, Bees, and Termites. Vander Meer RK, Breed MD, Winston ML, \& Espelie KE, eds., pp. 3-33. Westview Press, Boulder, Colorado.

Billen J \& Noll FB 2011. Morphology of Richards' gland in the wasp Metapolybia docilis. Sociobiology 58: 251-255.

Dani FR, Morgan ED, \& Turillazzi S 1995. Chemical analysis of sternal gland secretion of the paper wasp Polistes dominulus (Christ) and its social parasite Polistes sulcifer (Zimmermann) (Hymenoptera: Vespidae). J. Chem. Ecol. 21: 1709-1718.

Dani FR, Cannoni S, Turillazzi S, \& Morgan ED 1996. Ant repellent effect of the sternal gland secretion of Polistes dominulus (Christ) and P. sulcifer (Zimmermann). (Hymenoptera: Vespidae). J. Chem. Ecol. 22: $37-48$.

Downing HA 1991. The function and evolution of exocrine glands. In: The Social Biology of Wasps. Ross KG \& Matthews RW, eds., pp. 540-569. Cornell University Press, Ithaca, New York.

Hawkins JA, Hughes CE, \& Scotland RW 1997. Primary homology assessment, characters and character states. Cladistics 13: 275-283.

Heselhaus F 1922. Die Hautdrüsen der Apiden und verwandter Formen. Zool. Jahrb. Abt. Anat. Ontog. Tiere 43: 369-464.

Jeanne RL 1981. Chemical communication during swarm emigration in the social wasp Polybia sericea (Olivier). Anim. Behav. 29: 102-113.

1991. The Swarm-founding Polistinae. In: The Social Biology of Wasps. Ross KG \& Matthews RW, eds., pp. 191-231. Cornell University Press, Ithaca, New York.

Jeanne RL \& Post DC 1982. Richard's gland and associated cuticular modifications in social wasps of the genus Polybia Lepeletier (Hymenoptera, Vespidae, Polistinae, Polybiini). Insectes Soc. 29: 280-294.

Jeanne RL, Downing HA, \& Post DC 1983. Morphology and function of sternal glands in polistine wasps (Hymenoptera: Vespidae). Zoomorphology 103: 149-164.

Landolt PJ \& Akre RD 1979. Occurrence and location of exocrine glands in some social Vespidae (Hymenoptera). Ann. Entomol. Soc. Am. 72: 141-148.

Litte M 1981. Social biology of the polistine wasp Mischocyttarus labiatus: survival in a Colombian rain forest. Smithson. Contrib. Zool. 327: 1-27.

Martin SJ 1992. Colony defense against ant in Vespa. Insectes Soc. 39: 99-112.

Naumann MG 1975. Swarming behavior: evidence for communication in social wasps. Science 189: 642-644.

Nixon K \& Carpenter J 2012. On homology. Cladistics 28: $160-169$.

Noirot C \& Quennedey A 1974. Fine structure of insect epidermal glands. Annu. Rev. Entomol. 19: 61-80.

Patterson C 1982. Morphological characters and homology. In: Problems of Phylogenetic Reconstruction. Jossey KA \& Friday AE, eds., pp. 21-74. Academic Press, London and New York.

Post DC \& Jeanne RL 1980. Morphology of the sternal glands of Polistes fuscatus and P. canadensis (Hymenoptera: Vespidae). Psyche 87: 49-58.

Richards OW 1971. The biology of the social wasps (Hymenoptera, Vespidae). Biol. Rev. Camb. Philos. Soc. 46: 483-528.

Smith AR, O'Donnell S, \& Jeanne RL 2002. Evolution of swarm communication in eusocial wasps (Hymenoptera: Vespidae). J. Insect Behav. 15: 751-764.

Steinmetz I, Sieben S, \& Schmolz E 2002. Chemical trails used for orientation in nest cavities by two vespine wasps, Vespa crabro and Vespula vulgaris. Insectes Soc. 49: 354-356.

Turillazzi S 1979. Tegumental glands in the abdomen of some European Polistes (Hymenoptera: Vespidae). Monit. Zool. Ital. (NS) 19: 91-99. 